\title{
Effect of Satureja khuzistanica essential oil (SKEO) extract on expression of las A and lasB genes in Pseudomonas aeruginosa
}

\author{
Davoud Iman Islamieh ${ }^{1}$, Davoud Afshar ${ }^{2}$, Davoud Esmaeili ${ }^{1 *}$ \\ ${ }^{1}$ Department of Microbiology and Applied Microbiology Research Center, Systems Biology and Poisonings \\ Institute and Applied Virology Research Center, Baqiyatallah University of Medical Sciences, Tehran, Iran \\ ${ }^{2}$ Department of Microbiology and Virology, School of Medicine, Zanjan University of Medical Sciences, \\ Zanjan, Iran
}

Received: March 2018, Accepted: December 2018

\begin{abstract}
Background and Objectives: Expressions of las A and lasB genes of Pseudomonas aeruginosa are associated with bacterium pathogenicity. The present study was aimed to assess the effect of Satureja khuzistanica essential oil (SKEO) extract on expression of las $\mathrm{A}$ and las $\mathrm{B}$ genes in $P$. aeruginosa.

Materials and Methods: Pseudomonas aeruginosa isolates were cultured in Mueller Hinton broth containing sub-inhibitory concentrations of SKEO and total RNA extracted using Trizol method. cDNA was synthesized using random Hexamer primer and finally the expression of las A and lasB genes carried out by real-time PCR.

Results: The MICs of SKEO extract for PA9, PA10, PA11, PA13, PA41 and PA42 isolates were 8, 8, 8, 9, 7 and $12 \mu \mathrm{g} / \mathrm{ml}$, respectively. Statistical analysis for 6 isolates revealed that the reduction in expression of las A and las $\mathrm{B}$ genes under SKEO treatment was significant $(\mathrm{P}<0.05)$.

Conclusion: The insignificantly increasing of las B gene expression may lead to low virulent strains, for probably reason that the strain's exotoxin A are destroyed in the high amount of protease. In conclusion, using of SKEO in burned patients infected with $P$. aeruginosa may be effective; however, it is better to assess the spectrum activity of SKEO, pharmacokinetics, potency and its toxicity in human cells.
\end{abstract}

Keywords: Pseudomonas aeruginosa; Satureja khuzistanica essential oil; las A gene; lasB gene

*Corresponding author: Davoud Esmaeili, Ph.D, Department of Microbiology and Applied Microbiology Research Center, Systems Biology and Poisonings Institute and Applied Virology Research Center, Baqiyatallah University of Medical Sciences, Tehran, Iran.

Tel: +98218052941

Fax: +982177601533

Email: esm114@gmail.com

\section{INTRODUCTION}

Pseudomonas aeruginosa is a Gram negative pathogen responsible for nosocomial and opportunistic infections, which comebacks to organism's intrinsic resistance to many antibiotics and its virulence factors. There are many mechanisms, which causes bacterium to resist to antibiotics such as, expression 
of $\beta$-lactamases, antibiotic inactivating enzymes and over-expression of efflux pumps (1).

In healthy individuals, most of the infections that are related to $P$. aeruginosa are opportunistic rather than primary diseases.

Cystic fibrosis (CF) is one of the opportunistic infections with high prevalence and in most cases is associated with $P$. aeruginosa $(2,3)$, although multiple bacterial species could also involve in progressing of CF associated infection (4).

Hospital-acquired infections known as nosocomial infections are infections acquired by patient during hospitalization. These infections are caused by several organisms and $P$. aeruginosa is one of the commonly isolated organisms (5). Nosocomial infections are commonly occurred in many countries, which comeback to their low and limited hygiene level (6). Existing of multidrug resistance (MDR) bacteria such as $P$. aeruginosa has been made it as a new challenge to organize a successful plan to eradicate nosocomial infections. Recently, most of strains isolated from hospitalized patients have MDR phenotype and antibiotic resistance is also increasing among isolates (7). This subject compromise the efficacy of antimicrobial therapy and effort to find new antimicrobial agents.

$P$. aeruginosa has a more complicated pathogenesis, which comebacks to its several virulence genes involved in its pathogenicity. A number of virulence genes such astox $\mathrm{A}$, exoS, las $\mathrm{A}$ and las $\mathrm{B}$ have been identified in virulent strains (8). The las $\mathrm{A}$ and las $\mathrm{B}$ genes encode elastase enzymes, which have proteolytic activity and cause lung tissue and skin damages. Hence, the expression of these genes associated with species pathogenicity, especially in skin-burned patients (9).

Satureja khuzistanica is one of the native plants in Iran and its extract, Satureja khuzistanica essential oil (SKEO) traditionally used to treat patients with various diseases $(10,11)$.

The present study was aimed to assess the effect of SKEO extract on expression of las A and las B genes in MDR strains of $P$. aeruginosa.

\section{MATERIALS AND METHODS}

Preparation of plant. Aerial parts of S. khuzistanica plant were collected from Khorramabad of Iran during summer of 2013 and recognition and categorization of the plant substance performed by Barij Essence Company (Iran). The essential oil of plant was gained by steam distillation of plant and then dried with sodium sulphate at $4^{\circ} \mathrm{C}(12)$.

Bacterial isolates. A total of $6 P$. aeruginosa isolates with multidrug resistance phenotype (MDR) were cultured on MHA medium and incubated at $37^{\circ} \mathrm{C}$ for $24 \mathrm{~h}$.

Determination of MIC of SKEO oil. SKEO oil was dissolved in dimethyl sulfoxide (DMSO) with a final concentration of $0.1 \mathrm{mg} / \mathrm{mL}$ as stocke and stored at $4{ }^{\circ} \mathrm{C}$ away from heat and direct light. For each isolate, the volumes of 100, 120, 140, 160, 180, 200, 220 and $240 \mu \mathrm{l}$ of SKEO $(0.1 \mathrm{mg} / \mathrm{mL})$ were added into eight sterile glass tubes (13 by $100 \mathrm{~mm}$ ), reached on $2 \mathrm{ml}$ by MHB containing fresh cultures $\left(5 \times 10^{5} \mathrm{CFU} / \mathrm{ml}\right)$ and were finally incubated for 18 24 hours at $37^{\circ} \mathrm{C}$. About $10 \mu \mathrm{l}$ from incubated tubes were transferred on MHA and incubated for 18-24 hours at $37^{\circ} \mathrm{C}$. All tests were done in duplicate and positive and negative controls were also applied with bacteria and without oil, respectively.

RNA extraction. Following determination of MIC, isolates were cultured on LB broth with SKEO (at lower than MIC level) and incubated at $37^{\circ} \mathrm{C}$ for $24 \mathrm{~h}$. Extraction of total RNA was carried out using commercial RNA extraction kit (Trizol Reagent; BRL Life Technologies), electrophoresed in $1 \%$ gel agarose and visualized under UV light of gel documentation system (Bio-Rad, Germany). Concentration of the extracted RNA was measured at wavelength $260 \mathrm{~nm}$ using Nanodrop spectrophotometer ((Nano Drop, Wilmington, DE, USA). To remove genomic DNA contamination, all samples were treated with DNase-I (1U /1 $\mu \mathrm{g}$ RNA) and kept at $37^{\circ} \mathrm{C}$ for $0.5 \mathrm{~h}$. Lack of residual DNA was verified by PCR using RNA as a template (13).

cDNA synthesis. Synthesis of cDNA was carried out in a total volume of $20 \mu \mathrm{l}$ reaction mixture including $2 \mu \mathrm{g}$ of extracted RNA, $1 \mu \mathrm{l}$ of dNTPs $(10 \mathrm{mM})$, $50 \mathrm{ng}$ of random Hexamer primer, $2 \mu \mathrm{l}$ of $\mathrm{M}-\mathrm{MuLV}$ buffer (10X) and $100 \mathrm{U}$ of M-MuLV reverse transcriptase under an initial denaturation at $65^{\circ} \mathrm{C}$ for 5 min and reverse transcription steps at $42^{\circ} \mathrm{C}$ for $1 \mathrm{~h}$ (Vivantis, Malaysia). The products were immediately applied to RT-PCR and Real-time PCR assays. 
RT-PCR and Real-time PCR. The RT-PCR reaction was performed using Revert Aid first strand cDNA synthesis kit (Fermentas, USA) in a total volume of $25 \mu \mathrm{l}$ reaction mixture including $1 \mu \mathrm{g}$ of cDNA, (10 mM), and $0.3 \mathrm{pmol}$ of each primer (Table 1). PCR condition included an initial denaturation at $95^{\circ} \mathrm{C}$ for $2 \mathrm{~min}, 35$ cycles of $95^{\circ} \mathrm{C}$ for $30 \mathrm{~s}, 57^{\circ} \mathrm{C}$ for $30 \mathrm{~s}$ and $72^{\circ} \mathrm{C}$ for $30 \mathrm{~s}$ and a final extension at $72^{\circ} \mathrm{C}$ for 5 min. For internal control, gyrA was used. PCR products were electrophoresis in 1\% agarose gel and visualized under UV light of gel documentation system (Bio-Rad, Germany).

Real-time PCR was also carried out using Corbett Thermocycler model gradient Palm Cycler under following conditions: $12.5 \mu \mathrm{l}$ of Maxima SYBR Green/ ROX qPCR Master Mix 2X (Fermentas, USA), $2 \mu$ of templates and 0.3 pmol of each primer (Table 1). The relative calculation of the gene expression according to the Livak method ( $\Delta \Delta \mathrm{Ct}$ method), also known as $2^{-\Delta \Delta \mathrm{Ct}}$ or comparative $\mathrm{Ct}$ method, is performed without modifying its efficacy, and it is assumed that the desired doubling of target and reference DNA genes runs throughout each cycle. In this study, the results of Real-time PCR were analyzed by SPSS software and ANOVA test (14).

\section{RESULTS}

MIC of SKEO. For each isolate, the amount of 4, $5,6,7,8,9,10,11$ and $12 \mu \mathrm{g} / \mathrm{ml}$ of SKEOwere examined and their MIC results are shown in Table 2.

Effects of SKEO oil on lasA and lasB genes expression. Relative-quantitative gene expression levels of las A and las B genes were calculated to comparing with control gene ( $g y r \mathrm{~A})$. Melting curves of the target genes showed that there were any non-spe-

Table 1. Oligonucleotides used in study.

\begin{tabular}{lll}
\hline Primer & Sequence & $\begin{array}{l}\text { Amplicon } \\
\text { size (bp) }\end{array}$ \\
\hline lasA-F & TGCATTTCTCGCTGCTCTAC & 107 \\
lasA-R & GCGACAGTCGTTGTCGTAGT & \\
lasB-F & AGTTTGGACACGTCGATCAG & 78 \\
lasB-R & GCTTGACCTGTTGTTCGTTG & \\
gyrA-F & GGTCTGGGCATAGAGGTTGT & 121 \\
gyrA-R & GAAGATCGAGGGTATTTCCG & \\
\hline
\end{tabular}

Table 2. MICs of SKEO against $P$. aeruginosa isolates

\begin{tabular}{ll}
\hline P. aeruginosa isolates & MIC $(\boldsymbol{\mu g} / \mathbf{m l})$ SKEO \\
\hline PA9 & 8 \\
PA10 & 8 \\
PA11 & 8 \\
PA13 & 9 \\
PA41 & 7 \\
PA42 & 12 \\
\hline
\end{tabular}

cific amplicons or primer-dimers.

The result analysis by SPSS version 22 demonstrated relation gene expression before and after treatment is meaningful $(\mathrm{P}<0.05)$.

Statistical analysis for 6 isolates revealed the decline in expression of las $\mathrm{A}$ and las $\mathrm{B}$ genes under SKEO treatment was significant $(\mathrm{P}<0.05)$. However, at the different concentrations of SKEO, the expression rate of las $\mathrm{A}$ and las $\mathrm{B}$ genes were found to be insignificant $(\mathrm{P}>0.05)$.

\section{DISCUSSION}

Recently, the antimicrobial activity of S. khuzistanica has been shown to be associated more with its two important components: thymol and carvacrol $(15,16)$. In the present study, the effects of its extract (SKEO) on the expression of $P$. aeruginosa las A and las $\mathrm{B}$ genes were evaluated. These genes encode elastase enzymes, which play an important role in the pathogenicity of $P$. aeruginosa in burned patients (17).

As shown in the result paragraph, the MICs values of SKEO extract were partly similar among isolates, indicating a homogenous susceptibility against extract. The activity of herb extracts against bacteria has been previously shown. A study reported that in comparison with the Gram-positive bacteria, the Pseudomonas spp. were susceptible towards herb extracts (18).

In our study, while the SKEO extract decreased the expression of the las $\mathrm{A}$, the las $\mathrm{B}$ gene expression increased, insignificantly. Huerta et al. showed that some of herb extracts decreasing pyocyanin formation also reduced the expression and activity of elastase (19). This property indicates that the herb extracts may affect some factors that are commonly involved in the expression of pyocyanin synthesizing 
enzyme and elastase coding genes.

The results showed that the expression of las $\mathrm{B}$ gene $(\mathrm{P}>0.05)$ increased in different concentrations of SKEO, Insignificantly. It has been determined that the strains with high amount protease are less virulent and the strains with low amount protease cause more severe clinical symptoms. Destroying of exotoxin A by strains protease may be close to reality, although it may have many causes behind the production of protease and virulence capacity (20).

Pseudomonas aeruginosa has an enzyme called elastase, which is coded by las $\mathrm{A}$ and las $\mathrm{B}$ genes. This enzyme has the ability to decompose cytokines, leukocytes and defense cells, and also plays a role in the decomposition of lung and vascular elastin tissues. Ecthyma gangrenosum (EG) is a well-recognized but uncommon cutaneous infection classically associated with $P$. aeruginosa bacteremia. If it can be controlled gene virulence by the drug substance, it is possible to reduce the bacterial pathogenicity. This research demonstrated that $S$. khuzistanica can reduce the expression of las gene.

It seems that using of SKEO in burned patients infected with $P$. aeruginosa can be effective; however, it is better to assess the spectrum of activity, pharmacokinetics, potency and its toxicity in human cells and animal model.

\section{REFERENCES}

1. Mesaros N, Nordmann P, Plésiat P, Roussel-Delvallez M, Van Eldere J, Glupczynski Y, et al. Pseudomonas aeruginosa: resistance and therapeutic options at the turn of the new millennium. Clin Microbiol Infect 2007;13:560-578.

2. Davies JC. Pseudomonas aeruginosa in cystic fibrosis: pathogenesis and persistence. Paediatr Respir Rev 2002;3:128-134.

3. Møller SA, Jensen PØ, Høiby N, Ciofu O, Kragh KN, Bjarnsholt $\mathrm{T}$, et al. Hyperbaric oxygen treatment increases killing of aggregating Pseudomonas aerugino$s a$ isolates from cystic fibrosis patients. J Cyst Fibros 2019;:S1569-1993(19)30011-6.

4. Elborn JS, Vataire A-L, Fukushima A, Aballea S, Khemiri A, Moore C, et al. Comparison of inhaled antibiotics for the treatment of chronic Pseudomonas aeruginosa lung infection in patients with cystic fibrosis: systematic literature review and network meta-analysis. Clin Ther 2016;38:2204-2226.

5. Khan HA, Ahmad A, Mehboob R. Nosocomial in- fections and their control strategies. Asian Pac J Trop Biomed 2015;5:509-514.

6. Nyamogoba H, Obala A. Nosocomial infections in developing countries: cost effective control and prevention. East Afr Med J 2002;79:435-441.

7. System NNIS. National nosocomial infections surveillance (NNIS) system report, data summary from January 1992 through June 2004, issued October 2004. Am $J$ Infect Control 2004;32:470-485.

8. Nikbin V, Aslani MM, Sharafi Z, Hashemipour M, Shahcheraghi F, Ebrahimipour G. Molecular identification and detection of virulence genes among Pseudomonas aeruginosa isolated from different infectious origins. Iran J Microbiol 2012;4:118-123.

9. Kruczek C, Kottapalli KR, Dissanaike S, Dzvova N, Griswold JA, Colmer-Hamood JA, et al. Major transcriptome changes accompany the growth of Pseudomonas aeruginosa in blood from patients with severe thermal injuries. PLoS One 2016;11:e0149229.

10. Jafari F, Ghavidel F, Zarshenas MM. A critical overview on the pharmacological and clinical aspects of popular Satureja species. J. J Acupunct Meridian Stud 2016;9:118-127.

11. Mahboubi M, Attaran BJI. Satureja khuzistanica Jamzad essential oil and its anti-candidal activities against clinical isolates of Candida albicans isolated from women with candidiasis. Infectio 2019;23:16-21.

12. Hesham HAR, Abdurahman HN, Rosli MY. Techniques for extraction of essential oils from plants: a review. Aust J Basic Appl Sci 2016;10:117-127.

13. Hagen KE, Tannock GW, Korver DR, Allison GEJA. Detection, characterization, and in vitro and in vivo expression of genes encoding S-proteins in Lactobacillus gallinarum strains isolated from chicken crops. Appl Environ Microbiol 2005;71:6633-6643.

14. Livak KJ, Schmittgen TD. Analysis of relative gene expression data using real-time quantitative PCR and the 2(-Delta Delta C(T)) Method. Methods 2001;25:402408.

15. Seghatoleslami S, Samadi N, Salehnia A, Azimi S. Antibacterial activity of endemic Satureja khuzistanica Jamzad essential oil against oral pathogens. Iran Endod J 2009;4:5-9.

16. Du E, Gan L, Li Z, Wang W, Liu D, Guo Y. In vitro antibacterial activity of thymol and carvacrol and their effects on broiler chickens challenged with Clostridium perfringens. J Anim Sci Biotechnol 2015;6:58.

17. Meskini M, Esmaeili D. The study of formulated Zoush ointment against wound infection and gene expression of virulence factors Pseudomonas aeruginosa. BMC Complement Altern Med 2018;18:185.

18. Rakholiya K, Vaghela P, Rathod T, Chanda S. Comparative study of hydroalcoholic extracts of Momordica charantia L. against foodborne pathogens. Indian J 
Pharm Sci 2014;76:148-156.

19. Huerta V, Mihalik K, Crixell S, Vattem D. Herbs, spices and medicinal plants used in Hispanic traditional medicine can decrease quorum sensing dependent virulence in Pseudomonas aeruginosa. Int J Appl Res Nat Prod 2008;1:9-15.

20. Bennett JE, Dolin R, Blaser MJ. Principles and practice of infectious diseases: Elsevier Health Sciences 2014. Vol1. 